\title{
The daily water, sodium and potassium excretion in urine of Ghanaian children aged 5 to 12 years
}

\author{
*E. O. Badoe, W. Appeadu-Mensah, Afua Hesse and S. O. Maddy \\ Department of Surgery and Chemical Pathology. 'University of Ghana \\ Medical School, Accra, Ghana.
}

\begin{abstract}
Summary
Aim: The aim of the study was to determine the daily losses of water, sodium and potassium in the urine of Ghanaian children who presented to the paediatric surgery unit of the Korle-Bu teaching hospital.

Methods: The urine of 74 Ghanaian children (51 male, 23 female) who presented to the Paediatric surgery unit of the Korle-Bu teaching hospital between June 1997 and January 1999 was collected over a 24 hour period and analysed to determine the volume, sodium and potassium content.

Result: 74 children between the ages of 5 and 12 years with a mean age of 9 years were involved in the study. The mean daily urinary volume was $1136.8 \mathrm{ml}(95 \%$ confidence interval 1097.7 to 1176.0 ) with a range of 400 to $2400 \mathrm{ml}$. The sodium excreted was $108.6 \mathrm{mmol}$ per day (confidence interval 105.3 to 111.9) with a range of 39.8 to $231.9 \mathrm{mmol}$ per day while the potassium excreted was $24.7 \mathrm{mmol}$ (confidence interval 23.7 to $25.7 \mathrm{mmol}$ ) and a range of 6.25 to $69.9 \mathrm{mmol}$ per day.

'Conclusion: This study showed that children between 5 and 12 years in a ward lose a mean of $1136.8 \mathrm{ml}$ of water per day, $4.6 \mathrm{mmol}$ per kilogram of sodium per day, and $1 \mathrm{mmol}$ per $\mathrm{kg}$ per day of pottasium in their urine.
\end{abstract}

Key-words: Urinary water, Sodium and potassium, Children, 5 to 12 years.

\section{Résumé}

Le but: Le but de cette étude est de déterminer les niveaux des pertes quotidiens d'eau, de sodium et potassium dans l'urine des enfants Ghanéens qui se présentent à la Division de Chirurgie pédiatre au Centre hospitalier universitaire de Korle-Bu, Accra.

Methode: L'information à propos de l'urine de soixantequartorze (74) enfants Ghanéens, (50 garçons et 23 filles) se présentant à l'hopital entre Juin 1997 et Janvier 1999 recueillie pendant une période de 24 heures a été analysé pour determiner le volume, et le contenu de sodium et de potassium. Resultats: 74 enfants âgées de 5 à 12 ans avec l'âge moyen de 9 ans ont été inclu dans l'étude. Le volume d'urine quotidian moyen était $1136,8 \mathrm{ml}$ (95\% intervalle statisque 1097.7 à 1176.0) et une portée de 400 à 2,400 millilitres.

Le sodium excrété était $108,6 \mathrm{mmol}$ (intervalle statisque de 109,3 à 111.9) avec une portée de 39.8 à 231,9 mmols par jour.

Le potassium excrété était 24,7 (intervalle statisque de 23,7 à $25,7 \mathrm{mmol}$ ) avec une portée de 6,25 à 69,9 mmols par jour.

Conclusion: Cette étude démonstre que les enfants entre l'âge de 5 à 12 ans pendant une période d'hospitalisation perdent au moyen $1136,8 \mathrm{mls}$ d'eau par jour, 4,6 mmlo par $\mathrm{Kg}$ de sodium par jour et $1 \mathrm{mmol}$ par Kilogram de potassium par jour dans leur urine.

\section{Introduction}

Maintenance of normal fluid and electrolyte balance depends on a knowledge of the losses of water, sodium and potassium in urine, faeces and through the skin and lungs.

Studies done in temperate climates have been the basis for parenteral fluid and electrolyte therapy in our tropical environment in children.

Badoe $^{1}$, Badoe and Osafo ${ }^{2}$ and Elebute ${ }^{3}$, have shown that there are differences in fluid and electrolyte requirements between adults in the tropics and those in temperate climates.

Da Rocha et $\mathrm{al}^{4}$ have also shown differences in fluid requirements between neonates in the tropics and those in temperate climates.

No study of fluid and electrolyte losses of children in our environment has to our knowledge been conducted.

The purpose of this study was to determine the daily urinary losses of water, sodium and potassium of Ghanaian children aged 5 to 12 years, who reported for operation to the paediatric surgical unit of Korle-Bu Teaching hospital, Accra. Studies done by Badoe ${ }^{1}$ in Accra for a whole year, showed that while the temperature in the shade ranged from 18.3 to $34.4^{\circ} \mathrm{C}$, that in Surgical Ward Three, Korle-Bu Teaching Hospital varied between $20^{\circ} \mathrm{C}$ and $31.1^{\circ} \mathrm{C}$.

\section{Patients and methods}

Seventy four children, (51 male and 23 female) between the ages of 5 and 12 years, who presented to the Paediatric Surgical Unit of Korle-Bu Teaching Hospital, with surgical conditions that did not affect urine volume and electrolytes between June 1997 and January 1999, were included in the study.

Some of these children were admitted prior to surgery while others had recovered fully after surgery and were on a normal diet and fluid intake.

Those who were studied pre-operatively presented with herniae, hydroceles, undescended testes, hypospadias and some tumours. They were admitted $24 \mathrm{hr}$ before surgery during which period their urine was collected. Post-operative patients numbering 39, mostly had surgery for Acute Appendicitis, had fully recovered and were on a normal diet. They were ready for discharge but were detained further for their urine to be collected.

All of these patients were examined to ensure that they had no oedema, ascites, or systemic illness likely to affect the urinary parameters being studied. Their urine samples were tested for sugar, protein and pus cells.

Diet and fluid intake was not restricted in any way during the study.

Informed consent was obtained from the parents. Urine was collected in a Winchester jar over a 24-hour period. The volume of urine was determined with standard calibrated kidney dish, recorded and a sample sent to the laboratory for 
analysis of the sodium and potassium content.

The sodium and potassium ion concentrations were initially measured with a Jenway (Clinical PFP 7) Flame Photometer, (manufactured by Jenway Ltd. Felsted Dunmow Essex CM63LB England), by the method of Flame Emission Spectrophotometry. Later an ACEClinical chemistry analyser (manufactured by Schiaparelli Biosystems Inc., New Jersey, USA) using ion selective electrodes was used for these measurements, when this became available. The results were, however, comparable after some of the urine samples were tested using both methods.

Children in the 5 to 12 year age group were chosen in order to make collection of urine practicable.

The ages, heights and weights of the children were recorded. results.

The $95 \%$ confidence interval was used to analyse the

\section{Result}

Table 1

In all, 74 children ( 51 male and 23 female) between the ages of 5 and 12 years with a mean age of 9 years were involved in the study.

The mean weight was $23.6 \mathrm{~kg}$ with a $95 \%$ confidence interval of 23.1 to $24.1 \mathrm{~kg}$ and a range of 14 to $40 \mathrm{~kg}$.

The volume of urine obtained was a mean of $1136.8 \mathrm{ml}$ with a $95 \%$ confidence interval of 1097.7 to $1176.0 \mathrm{ml}$ and a range of 400 to $2400 \mathrm{ml}$. This was equivalent to about $2.0 \mathrm{ml}$ per $\mathrm{kg}$. per hour.

The sodium exreted was a mean of $108.6 \mathrm{mmol}$ per day with a confidence interval of 105.3 to $111.9 \mathrm{mmol}$ and a range
The sodium loss was $108.6 \mathrm{mmol}$ ( 39.8 to $231.9 \mathrm{mmol}$ ) daily. This was a mean of $4.6 \mathrm{mmol}$ per $\mathrm{kg}$ per day. The normal urinary loss of sodium of children in the temperate climate has been reported as 2 to $3 \mathrm{mmol}$ per $\mathrm{kg}$ per day. ${ }^{5}$ It seems, therefore, that the sodium requirement in the age group studied may be higher than that in temperate regions. This is based on the fact that the children studied lost more sodium in their urine than those in temperate regions.

The potassium exreted, $24.7 \mathrm{mmol}$ (6.25 to $69.9 \mathrm{mmol})$ per day was equivalent to a mean of $1.0 \mathrm{mmol}$ per $\mathrm{kg}$ per day. The reported daily loss of potassium in children is about 1 to $2 \mathrm{mmol}$ per $\mathrm{kg}$. per day. ${ }^{5}$ This is similar to the results obtained in this study.

Possible effects of surgery on electrolytes include sodium and water retention. However, by waiting till the children were 4 to 5 days post-op., and were on a normal diet and fluid intake this effect if any was made insignificant. The results in fact showed an increased loss of sodium rather than retention.

\section{Conclusion}

The urinary water and potassium excretion of children between 5 and 12 years in our environment is similar to those in the temperate climates but more sodium is excreted in the urine of our children.

\section{Acknowledgements}

We wish to thank the nursing staff of the Paediatric surgical ward and the staff of Chemical Pathology, University of Ghana Medical School and Chemical Pathology, National Cardiothoracic Centre for their assistance and cooperation.

Table 1 Average daily urinary losses

\begin{tabular}{|c|c|c|c|c|c|c|}
\hline $\begin{array}{c}\text { Age } \\
\text { (Years) }\end{array}$ & $\begin{array}{c}\text { Volume of } \\
\text { Urine/Total } \\
\text { Daily } \\
\text { loss }(\mathrm{Ml})\end{array}$ & $\begin{array}{l}\text { Volume of } \\
\text { Urine/ } \\
\text { Loss } / \mathrm{Kg} \\
\text { hour (Ml } \\
\mathrm{kg} / \mathrm{hr} \text {.) }\end{array}$ & $\begin{array}{c}\text { Sodium } \\
\text { Total } \\
\text { Daily } \\
\text { loss } \\
\text { (mmol) }\end{array}$ & $\begin{array}{l}\text { Sodium } \\
\text { Loss/Kg/ } \\
\text { day } \\
\text { (Mmol/ } \\
\mathrm{kg} / \text { day) }\end{array}$ & $\begin{array}{c}\text { Potassium } \\
\text { Total Daily } \\
\text { loss } \\
\text { (Mmol) }\end{array}$ & $\begin{array}{c}\text { Potassium } \\
\text { Loss/Kg/ } \\
\text { day } \\
\text { (Mmol/ } \\
\text { kg/day) }\end{array}$ \\
\hline $5-12$ & $\begin{array}{l}1136.8 \\
(400 \text { to } \\
2400)\end{array}$ & 2 & $\begin{array}{c}108.6 \\
(39.8 \text { to } \\
231.9)\end{array}$ & 4.6 & $\begin{array}{c}24.7 \\
(6.25 \text { to } \\
69.9)\end{array}$ & 1.0 \\
\hline
\end{tabular}

of 39.8 to $231.9 \mathrm{mmol}$. This mean was equivalent to $4.6 \mathrm{mmol}$ per $\mathrm{kg}$. per day.

The mean potassium excreted was $24.7 \mathrm{mmol}$ per day with a confidence interval of 23.7 to $25.7 \mathrm{mmol}$ and a range of 6.25 to $69.9 \mathrm{mmol}$. This was equivalent to $1.0 \mathrm{mmol}$ per $\mathrm{kg}$. per day.

\section{Discussion}

Normal fluid and electrolyte therapy is based on a knowledge of the daily losses in urine, skin, lungs and faeces.

In this study, the daily losses of water, sodium and potassium in the urine of 74 Ghanaian children aged 5 to 12 years in the Paediatric Surgery unit of Korle-Bu Teaching Hospital were determined.

The mean volume of urine was $1136.8 \mathrm{ml}$ ( 400 to $2400 \mathrm{ml}$ ), an average of $2,0 \mathrm{ml}$ per $\mathrm{kg}$ per hour. This volume is the same as in temperate climates. ${ }^{5}$
We also thank Ms Basilia Gayo, Department of Surgery, UGMS for her secretarial assistance.

Our special thanks goes to Professor R. B. Biritwum who did the statistical analysis and Professor K. A. Oduro who encouraged us during the execution of the project.

The project was generously supported financially by Intravenous infusion Ltd., Koforidua, Ghana. We thank the company.

\section{References}

1. Badoe E A. Pulmonary and cutaneous fluid losses of the adult Ghanaian in Korle-Bu Hospital, Accra, Ghana Med J. 1968; 7 : $59-61$.

2. Badoe E A, Osafo T D. The daily urinary volume, sodium and potassium in adult Ghanaians. The West African medical journal 1978; 20: $226-227$. 
3. Elebute E A. Evaporation, fluid loss in adult Nigerian males Br. J Surg. 1969;213 - 216.

4. Da Rocha-Afodu J T, Aina A O, Atimomo C E. Fluids and electrolytes studies in Nigerian children. W. A. J. Med. 1985;
4: $149-154$.

5. Letton R W, Chwals W J. Fluid and electrolyte management in "Surgery of children" Ed Oldham K T, Coleman P M and Foglia R P. 1997; 92 - 93. Lippincott Raven, Philadelphia. 